\title{
Ultramafic mantle assemblages from Sytykanskaya kimberlite pipe (Yakutia)
}

\author{
Reimers, L.F., Pokhilenko, N.P., Yefimova, E.S., Sobolev, N.V.
}

Institute of Mineralogy and Petrography, Siberian Branch of Russian Academy of Sciences, Novosibirsk, 630090, Russia

Upper Devonian (344 Ma old) Sytykanskaya pipe (Davis et al., 1980) is situated in the DaldynAlakit region of the Yakutian Diamondiferous Province among Lower Paleozoic sedimentary deposits. The pipe is filled in with four or five varieties of eruptive kimberlite breccia. The widespread postmagmatic processes resulted in considerable alteration of the primary xenolith material.

A collection of xenoliths of mantle ultramafic rocks (260 specimens) and diamonds with inclusions ( 300 crystals) was under study. Among the xenoliths, granular varieties of garnet and garnet-spinel peridotites play a leading role, amounting about $70 \%$; sheared peridotites are quite rare. Xenoliths of ilmenite-garnet peridotites with signs of metasomatism and shearing are sufficiently widespread $(\sim 15 \%)$. The diamonds from the Sytykanskaya Pipe are genetically related chiefly to the ultramafic paragenesis.

Olivine from the peridotite xenoliths is represented by magnesian varieties $(m g=88.7-92.2)$. An admixture of $\mathrm{Cr}_{2} \mathrm{O}_{3}$ reaches up to $0.09 \mathrm{wt} . \%, \mathrm{CaO}$ ranges from 0.01 to $0.35 \mathrm{wt} . \%$. Compositionally, the olivines from diamonds are similar to the varieties described earlier (Meyer, 1987). These are forsterites ( $\mathrm{mg}$ varies from 88.9 to 94.0$)$ with an insignificant admixture of $\mathrm{CaO}(0.02 \mathrm{wt} . \%$ on the average) and with a persistent admixture of $\mathrm{Cr}_{2} \mathrm{O}_{3}(0.01-0.08$ wt.\%).

Enstatites, included in diamonds, are also similar to the majority of inclusions $\left(\mathrm{Al}_{2} \mathrm{O}_{3}-0.21-0.43\right.$; $\mathrm{Cr}_{2} \mathrm{O}_{3}-0.20-0.34 \mathrm{wt} . \%$ ); in peridotites they are completely altered.

Clinopyroxenes of xenoliths are typical chrome diopsides. Their $m g$ ranges between 87.8-95.0. Chrome diopsides from diamonds have $m g$ from 89.4 to 93.9 . The grains of cubcalcic relatively hightemperature clinopyroxenes $(100 \mathrm{Ca} /(\mathrm{Ca}+\mathrm{Mg})$ ratios equal 37.6 and 40.2$)$ are characterized by the lower $m g$ ( 89.7 and 89.4 respectively). The peridotite clinopyroxenes are significantly enriched in sodium (0.73-6.38 wt.\% $\mathrm{Na}_{2} \mathrm{O}$, averaging 3.00 wt.\%) and $\mathrm{Cr}\left(0.48-6.00\right.$ wt. $\% \mathrm{Cr}_{2} \mathrm{O}_{3}$, averaging 2.70 wt.\%). A persistent admixture of $\mathrm{K}_{2} \mathrm{O}$ in the clinopyroxenes from xenoliths and from diamonds does not exceed $0.07 \mathrm{wt} . \%$ and reaches $0.27 \mathrm{wt} . \%$, respectively.

In the composition of $\mathrm{Cr}$-spinels from the ultramafic xenoliths the maximum variations are observed in $\mathrm{Cr}_{2} \mathrm{O}_{3}$ and $\mathrm{Al}_{2} \mathrm{O}_{3}$ relations at a low permanent $\mathrm{TiO}_{2}$ admixture. An increase in $\mathrm{TiO}_{2}$ (up to 3.91 wt.\%) along with elevated $\mathrm{Fe}^{3+}$ leads to increasing of ulvöspinel and magnetite proportion. The diamond related $\mathrm{Cr}$-spinels are compositionally similar to worldwide diamond inclusions (Meyer, 1987).

Picroilmenites from peridotite xenoliths contain $\mathrm{MgO}$ from 7.29 to $15.8, \mathrm{Al}_{2} \mathrm{O}_{3}$ - from 0.06 up to 0.99 , and $\mathrm{Cr}_{2} \mathrm{O}_{3}$ from 0.38 to $7.10 \mathrm{wt} . \%$. On the whole, the ilmenites from the Sytykanskaya pipe xenoliths are somewhat richer in $\mathrm{Cr}$ as compared with a number of other bodies in the Daldyn-Alakit region.

The absolute majority of the studied peridotite xenoliths contains garnets with the Ca-content, typical of lherzolite paragenesis (Sobolev et. al, 1973). In general, the content of $\mathrm{Cr}_{2} \mathrm{O}_{3}$ in garnets from granular peridotites ranges from 0.33 to $12.3 \mathrm{wt} . \%$. $\mathrm{mg}$ of garnets varies within 73.8-89.9. It decreases down to 72.0 for the ilmenite-bearing peridotites. The average content of $\mathrm{TiO} 2$ is 0.27 wt. $\%$ with variations from 0.01 to $2.07 \mathrm{wt} . \%$ (in the ilmenite-containing xenoliths the average is 0.56 wt. \% with variations from 0.10 to 1.35 wt.\%). For peridotite garnets a stable isomorphic $\mathrm{Na}_{2} \mathrm{O}$ admixture (up to $0.17 \mathrm{wt.} \%$, averaging $0.06 \mathrm{wt} . \%$ ) is determined (Sobolev, Lavrent'ev, 1971) which 
is directly correlated with the contents of $\mathrm{Ca}$, $\mathrm{Ti}$ and $\mathrm{Fe}$. Signs of metasomatism and heterogeneities in the composition of the mineral phases caused by solid-state reactions in the course of thermodynamic evolution of the mantle substrate are observed in a considerable (about $15 \%$ ) number of peridotite xenoliths from Sytykanskaya pipe. The heterogeneities recognized there are as follows: a) zoning of large (up to $8 \mathrm{~mm}$ ) grains of garnet in the ilmenite-garnet peridotite xenoliths with traces of melting and deformations, with $\mathrm{Ca}$ and $\mathrm{Cr}$ depletion and $m g$ decrease along with the increase of the Ti-content towards the rim; b) zoning of garnets in the sheared garnet lherzolite xenoliths, with the grain periphery enriched in $\mathrm{Ca}, \mathrm{Ti}, \mathrm{Fe}, \mathrm{Na}$, and some incompatible elements $(\mathrm{Zr}$, $\mathrm{Y}, \mathrm{Ga}$ ) and depleted in $\mathrm{Cr}$ and $\mathrm{Sr}$; c) significant variations in grain compositions of the same mineral, e.g. garnet, homogeneous inside a grain, in separate sites of the xenolith, up to the change of paragenesis in one specimen (Fig.).

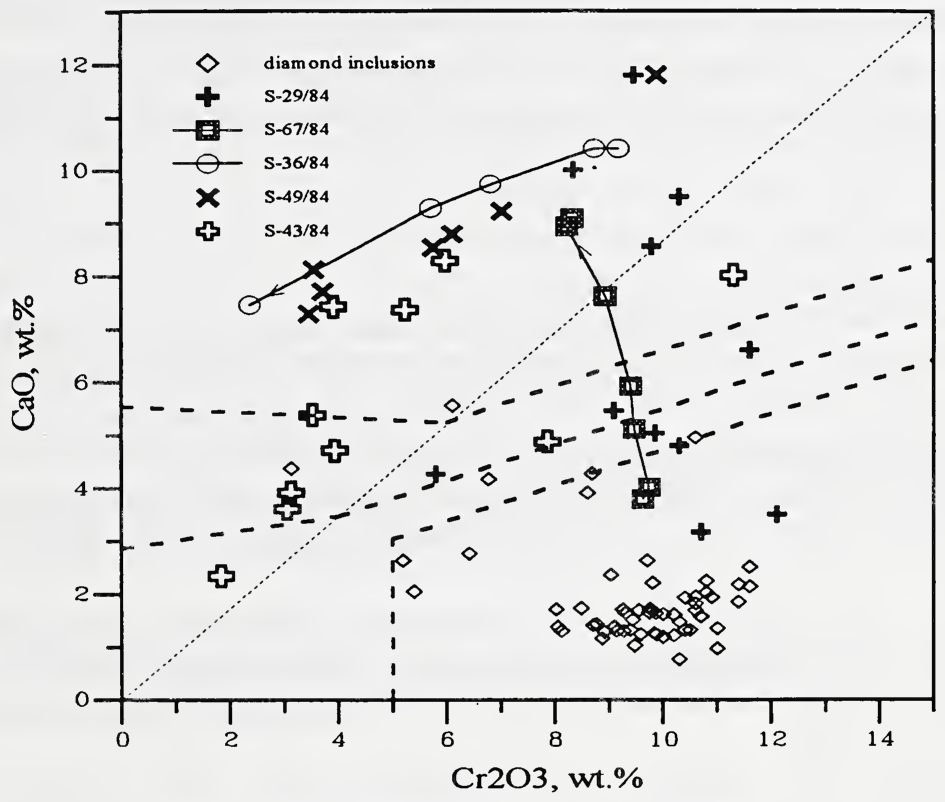

Fig. $\mathrm{Cr}_{2} \mathrm{O}_{3}$ vs $\mathrm{CaO}$ diagram for chrome pyropes from Sytykanskaya pipe. Diamonds - diamond inclusions; unequilibrated and zoned pyrope grains from xenoliths of granular (samples S-29/84, S-67/84, S-43/84) and ilmenitebearing peridotites (samples S-36/84, S-49/84) with signs of shearing are shown by other symbols. The core-rim direction is marked by arrows.

A typical feature of the garnets of dunite-harzburgite paragenesis from the Sytykanskaya pipe diamonds is their rather stable very low content of $\mathrm{Ca}(\mathrm{CaO}$ is $1.78 \mathrm{wt} . \%$ on the average) and significant variations in $\mathrm{Cr}$ content $\left(\mathrm{Cr}_{2} \mathrm{O}_{3}\right.$ is $\left.5.19-11.6 \mathrm{wt} . \%\right)$, which resembles Finsch pipe diamond inclusions (Gurney et al., 1979). The chrome pyropes from diamonds contain very low sodium: 0.010.05 wt. $\% \mathrm{Na}_{2} \mathrm{O}$. Two available inclusions of lherzolitic garnets are characterized by elevated $\mathrm{TiO}_{2}$ content (0.90 and $1.11 \mathrm{wt} . \%)$ and lower $\mathrm{mg}$ (84.6 and 82.6 respectively) as compared to the depleted harzburgite dunite compositions. In chemistry, these grains are similar to the garnet from diamondiferous sheared ilmenite-garnet lherzolite (Pokhilenko et al., 1976), interpreted as a fragment of weakly depleted «hot» mantle. 
The results of the investigation of diamond inclusions show that the parental rocks for the absolute majority of diamonds of Sytykanskaya pipe are extremely depleted harzburgite-dunites.

Comparative analysis of rock-forming mineral compositions evidences for significant inhomogeneities (see Fig.) possibly related to the instability of PT-parameters and environmental chemistry due to metasomatism processes. The mantle shearing leading to the rock deformation and recrystallization was favourable for depth high-temperature metasomatism, assisting penetration of fluids. This is confirmed by the signs of significant plastic deformations, shearing and partial melting in the rocks, containing nonequilibrium mineral assemblages. The most probable mechanism of the formation of the these assemblages seems to be a mechanical mixing of the matter from separate interlayers in local zones of mantle fracturing. The formation of contaminated rocks, "polymict peridotites» according to Lawless et al. (1979) or the "mantle melanites" (Laz'ko, Serenko, 1991) is a result of shearing stresses along with a mixing of partially melted peridotite substrate. Combined with shearing and partial melting of matter, the processes of mantle metasomatism seemed to immediately preceded the formation of kimberlite melts and transportation of nonequilibrium assemblages to the Earth's surface, where they remained in the metastable state.

Thus, Sytykanskaya pipe is characterized by a high-grade primary differentiation, vertical heterogeneity of the Upper Mantle and high intensity of the mantle metasomatic processes.

\section{References}

Davis, G.L., Sobolev, N.V., Kharkiv, A.D.,1980, New data on the age of Yakutian kimberlites obtained by the U-Pb method on zircons (in Russian): Dokl. Akad. Nauk SSSR, v.254, pp.175-179. Gurney, J.J., Harris, J.W., Rickard, R.S., 1979, Silicate and oxide inclusions from the Finsch kimberlite pipe: Proc. 2-nd Int. Kimberlite Conf., v.1, AGU, Washington, p. 1-15.

Lawless, P.J., Gurney, J.J., Dawson, J.B., 1979, Polymict peridotites from Bultfontein and De Beers Mines, Kimberley, South Africa: Proc. 2-nd Int. Kimberlite Conf., v. 2, AGU, Washington, p. 145-155.

Laz'ko, E.E., Serenko, V.P., 1991, Unequilibrated ultramafic xenoliths from Udachnaya kimberlite pipe, Western Yakutia: 5-th Int. Kimberlite Conf., Ext.Abstr., Araxa, Brazil, p. 228-230.

Meyer, H.O.A., 1987, Inclusions in diamond: Nixon P.H. ed., Mantle xenoliths, John Wiley \& Sons, Chichester, England, p. 501-523.

Pokhilenko, N.P., Sobolev, N.V., Sobolev, V.S., Lavrent'ev, Yu.G., 1976, Xenolith of diamondbearing ilmenite-pyrope lherzolite from Udachnaya kimberlite pipe (Yakutia) (in Russian): Dokl. Acad. Nauk SSSR, v. 231, N 2, p. 438-441.

Sobolev, N.V., Lavrent'ev, Yu.G., 1971, Isomorphic sodium admixture in garnets formed at high pressures: Contrib. Mineral. Petrol., v. 31, p. 1-12.

Sobolev, N.V., Lavrent'ev, Yu.G., Pokhilenko, N.P., Usova, L.V., 1973, Chrome-rich garnets from kimberlites of Yakutia and their parageneses: Contrib. Mineral. Petrol., v. 40, p. 39-52. 